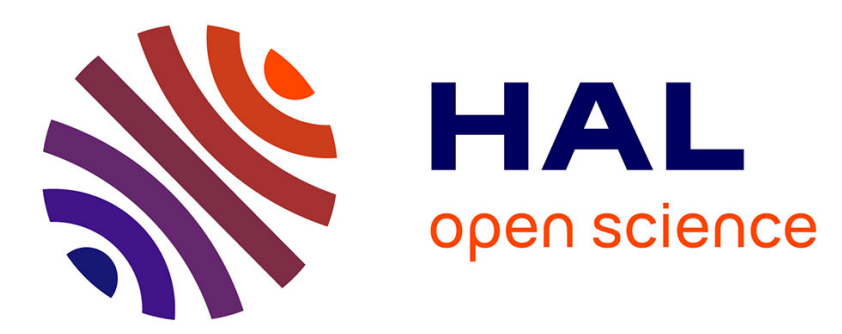

\title{
On the kinetics of the nitrate reduction in concentrated nitric acid
}

\author{
Ronny Lange, Emmanuel Maisonhaute, Raphaël Robin, Vincent Vivier
}

\section{To cite this version:}

Ronny Lange, Emmanuel Maisonhaute, Raphaël Robin, Vincent Vivier. On the kinetics of the nitrate reduction in concentrated nitric acid. Electrochemistry Communications, 2013, 29, pp.25-28. 10.1016/j.elecom.2013.01.005 . hal-00803492

\section{HAL Id: hal-00803492 https://hal.sorbonne-universite.fr/hal-00803492}

Submitted on 3 Mar 2015

HAL is a multi-disciplinary open access archive for the deposit and dissemination of scientific research documents, whether they are published or not. The documents may come from teaching and research institutions in France or abroad, or from public or private research centers.
L'archive ouverte pluridisciplinaire $\mathbf{H A L}$, est destinée au dépôt et à la diffusion de documents scientifiques de niveau recherche, publiés ou non, émanant des établissements d'enseignement et de recherche français ou étrangers, des laboratoires publics ou privés. 


\title{
On the kinetics of the nitrate reduction in concentrated nitric acid
}

\author{
Ronny Lange ${ }^{\mathrm{a}, \mathrm{b}, \mathrm{c}}$, Emmanuel Maisonhaute ${ }^{\mathrm{a}, \mathrm{b}}$, Raphaël Robin ${ }^{\mathrm{c}}$, \\ Vincent Vivier ${ }^{\mathrm{a}, \mathrm{b},{ }^{*}}$ \\ ${ }^{a}$ CNRS, UPR15, Laboratoire Interfaces et Systèmes Electrochimiques, F-75005 Paris, France \\ ${ }^{b}$ UPMC Univ Paris 06, UPR15, LISE, 4 place Jussieu, F-75005 Paris, France \\ ${ }^{c}$ CEA/DEN/DANS/DPC/SCCME/LECNA, 91191 Gif sur Yvette, France
}

\begin{abstract}
The autocatalytic mechanism involved in the reduction reaction of nitrate in $8 \mathrm{M}$ nitric acid solution was investigated in order to propose a complete description of all processes taking place at the interface. A time and potential independent current plateau was observed for low scan rates and was ascribed to limitation by the desorption of $\mathrm{NO}_{\mathrm{ads}}$. Data analysis and fit of the experimental chronoamperogram allowed determination of the kinetic constants of the autocatalytic cycle.
\end{abstract}

Keywords: autocatalysis, nitrate reduction, nitric acid, chronoamperometry.

* Corresponding author.

V. Vivier Tel.: +33-1-44274158; fax: 33-1-44274074

E-mail address: vincent.vivier@upmc.fr 


\section{Introduction}

Nitric acid acts as a strong oxidizing agent and is involved in several industrial processes that can take place in concentrated solutions, stimulating fundamental investigations over decades of electrochemical reactions in this medium $[1,2]$. For instance, this reduction reaction is involved into the corrosion rate of stainless steel [3, 4], but also into applications for the removal of nitrite from ground water, or for the synthesis of hydroxylamine derivatives $[5,6]$. Since the reduction of nitrate in concentrated nitric acid solutions involves several autocatalytic cycles, local concentrations can change rapidly in the vicinity of the interface, causing significant change in the total reaction rate. In the low concentration domain $(<0.1 \mathrm{M})$ a direct reaction mechanism involving nitrate ion adsorbate that undergoes an electron transfer has been well described in the literature $[5,6]$. For higher nitrate concentration and in presence of nitrite, two different indirect routes for the nitrate ion reduction have been proposed by Vetter [7] and Schmid [8, 9], respectively, both taking place at small overpotentials $[10,11]$. The heterogeneous Vetter mechanism is supposed to occur at higher potentials and poorly depends on stirring of the solution since the rate determining step involves adsorbates. Conversely, the homogeneous Schmid mechanism shows a very strong correlation with the mass transfer of redox species. Since autocatalysis occurs in solution, stirring the solution involves a diminution of current density [13]. It is however difficult to clearly distinguish between these two mechanisms, because they are coupled through some identical reactions [12]. In the present study performed in concentrated acidic solution with millimetric-sized electrodes, the Schmid mechanism dominates when there is no stirring. It can be described by the following set of elementary reactions:

$$
\begin{array}{ll}
\mathrm{HNO}_{2}+\mathrm{H}^{+} & \rightleftarrows \mathrm{NO}^{+}+\mathrm{H}_{2} \mathrm{O} \\
\mathrm{NO}^{+} & \rightleftarrows \mathrm{NO}^{+}{ }_{\text {(ads) }}
\end{array}
$$




$$
\begin{array}{ll}
\mathrm{NO}_{(\text {ads })}^{+}+\mathrm{e}^{-} & \rightleftarrows \mathrm{NO}_{(\text {ads })} \\
\mathrm{NO}_{(\text {ads })} & \rightleftarrows \mathrm{NO} \\
\mathrm{HNO}_{2}+\mathrm{HNO}_{3} & \rightleftarrows \mathrm{N}_{2} \mathrm{O}_{4}+\mathrm{H}_{2} \mathrm{O} \\
\mathrm{N}_{2} \mathrm{O}_{4} & \rightleftarrows 2 \mathrm{NO}_{2} \\
\mathrm{NO}_{2}+\mathrm{NO}+\mathrm{H}_{2} \mathrm{O} & \rightleftarrows 2 \mathrm{HNO}_{2}
\end{array}
$$

At the electrode interface, the net balance of the overall reaction results in an excess of one nitrous oxide molecule per electron. The convection dependence of the system was evidenced by stirring the solution causing a decrease of the current due to the removal of $\mathrm{HNO}_{2}$ from the interface [13]. Conversely to the seminal work of Andrieux et al. on the dissociative electron transfer in alkyl halide compounds [14], the mechanism proposed in this work involves $\mathrm{NO}^{+}$ and NO as adsorbed intermediates. This seems plausible since outer sphere electron transfer would involve a large reorganization energy for this couple [15].

The purpose of this report is to get an insight into the reduction mechanism of nitrate in concentrated acidic solution and propose a simplified mechanism that accounts for the chronoamperometric and the voltametric response observed on a Pt electrode. Special attention is paid to the fitting of the results leading to a quantitative analysis of this complex autocatalytic process.

\section{Materials and Methods}

\subsection{Chemicals}

Nitric acid solutions were prepared by mixing $68 \mathrm{wt} \% \mathrm{HNO}_{3}$ (VWR International) with twice distilled water. Since it was crucial to perform our experiments in macroscopically still solutions, we choose to work at room temperature $\left(20 \pm 2^{\circ} \mathrm{C}\right)$ and without deaerating the solutions. All measurements were carried out in freshly prepared $8 \mathrm{M} \mathrm{HNO}_{3}$.

\subsection{Electrodes}


A platinum wire of $250 \mu \mathrm{m}$ in radius (Goodfellow, 99.99\% purity) was sealed into a borosilicate glass capillary. Electrical contact between the platinum and a copper connector was achieved with a conducting silver-glue. The electrode was polished with an abrasive Si-C paper (up to grade 4000) and prior to each experiment, the platinum surface of the electrode was cleaned electrochemically in $1 \mathrm{M} \mathrm{H}_{2} \mathrm{SO}_{4}$ by performing cyclic voltammetry using the adsorption peaks of hydrogen as reference system.

\subsection{Electrochemical measurements}

All measurements were performed with a home-built potentiostat controlled by a Labview software. The experiments were carried out in a conventional three-electrode cell, with a saturated mercury/mercurous sulfate reference electrode (SSE) and a platinum gauze as counter electrode.

\subsection{Electrochemical simulation}

Chronoamperometry results were analyzed using DigiElch simulation software.

\section{Results and Discussions}

Fig. 1a shows a linear potential scan of a $250 \mu \mathrm{m}$ in radius $\mathrm{Pt}$ electrode at $10 \mathrm{mVs}^{-1}$ in a $8 \mathrm{M}$ $\mathrm{HNO}_{3}$ solution. It is commonly admitted that the huge current enhancement by $c a$. two orders of magnitude observed in the 0.3 to $-0.2 \mathrm{~V} / \mathrm{SSE}$ region is due to the establishment of the Schmid autocalatytic reaction. It has been demonstrated that the current decrease at more negative potentials is due to adsorption of $\mathrm{N}_{2} \mathrm{O}$ (obtained from further reduction of NO) that blocks adsorption of the $\mathrm{NO}^{+} / \mathrm{NO}$ couple [3]. Moreover, the investigation of the scan rate influence on the current in the same solution (Fig. 1b) shows that a current plateau is observed as soon as the scan rate gets smaller than about $0.3 \mathrm{Vs}^{-1}$ which gives a first rough estimation of the characteristic time for the autocatalysis to start. At higher scan rates, catalysis is progressively blocked. In the high scan rates regime, the current increases linearly with the 
scan rate as expected for voltammetry of adsorbed intermediates. This plateau was not observed in the previously published papers at lower concentrations $[5,16]$. The voltammetric observations are in full agreement with the chronoamperometric trace performed at $0 \mathrm{~V} / \mathrm{SSE}$ displayed in Figure 2. The current plateau is thus almost time and potential independent, and corresponds to an extremely high current density of $c a .1 \mathrm{Acm}^{-2}$.

In the mechanism proposed above, only the desorption of $\mathrm{NO}_{\text {ads }}$ is independent of the reactant concentrations which evolves with time and can thus be invoked to explain this plateau. In this regime, the current is expressed as:

$$
i / \mathrm{FS}=k_{\mathrm{des}} \Gamma_{\mathrm{Max}}
$$

where $k_{d e s}$ is the kinetic constant of NO desorption, and $\Gamma_{\text {Max }}$ is the maximal surface coverage. In other words, reactions in the solution provide enough $\mathrm{NO}^{+}$so that its adsorption is not the limiting step. It is noteworthy that the current allows to determine the product $k_{d e s} \Gamma_{\text {Max }}$, and thus the independent measurement of the surface coverage give access to kinetic constant of the desorption.

From several chemical considerations, the Schmid mechanism can be simplified as follows:

- $\mathrm{N}_{2} \mathrm{O}_{4}$ is an unstable species, which is probably present in negligible amounts. The steady state approximation performed on this compounds allows equations (5) and (6) to be simplified as:

$$
\mathrm{HNO}_{2}+\mathrm{H}^{+}+\mathrm{NO}_{3}{ }^{-} \rightleftarrows \mathrm{H}_{2} \mathrm{O}+2 \mathrm{NO}_{2} \quad k_{9}=k_{5} \quad \text { (Eq. 9) }
$$

in which Eq. 5 is the rate limiting step.

- Because of the large excess of protons in solution, the conversion of $\mathrm{HNO}_{2}$ to $\mathrm{NO}^{+}$ (Eq.1) is not rate limiting. 
- Whether $\mathrm{HNO}_{3}$ is dissociated or not little affects the simulations. We assume that $\left[\mathrm{H}^{+}\right]$ is uniform and does not vary during the duration of the experiments. Thus, its effects are incorporated in the various rate constants $\left(\mathrm{k}_{1}, \mathrm{k}_{5}\right.$, and $\left.\mathrm{k}_{\mathrm{ads}}\right)$.

We therefore suggest the following simplified mechanism:

$$
\begin{array}{ll}
\mathrm{HNO}_{2 a q}+\mathrm{H}^{+} \rightarrow \mathrm{NO}^{+}{ }_{a d s}+\mathrm{H}_{2} \mathrm{O} & k_{a d s} \\
\mathrm{NO}^{+}{ }_{a d s}+e^{-} \rightleftarrows \mathrm{NO}_{a d s} & k_{\text {het }} \\
\mathrm{NO}_{\text {ads }} \rightarrow \mathrm{NO} & k_{\text {des }}
\end{array}
$$

and the formation of $\mathrm{HNO}_{2}$ occurs through Eqs. 7 and 9.

Figure 2a shows the chronoamperometric response of the Pt electrode initially at the open circuit potential to a potential step at $0 \mathrm{~V} / \mathrm{SSE}$. For the short times (inset in Fig. 2a), the chemical reactions are blocked so that the initial current decrease corresponds to standard chronoamperometric response. Its amplitude thus depends strongly on the initial concentration of $\mathrm{HNO}_{2}$ that can vary with the aging of the stock solution.

If no NO is initially present in the solution, and since this species is produced only by desorption (Eq. 4), its presence may hinder autocatalysis at intermediate times (Eq. 7). But once sufficient amount of NO has been produced in the electrode vicinity, Eq. 7 is fast enough so that the rate becomes then limited by reaction 9 . Steady state approximation can thus be performed on $\mathrm{NO}_{2}$. Eqs. 7 and 9 can then be rewritten as:

$$
\mathrm{HNO}_{2}+\mathrm{H}^{+}+\mathrm{NO}_{3}^{-}+2 \mathrm{NO}+\mathrm{H}_{2} \mathrm{O} \rightarrow 4 \mathrm{HNO}_{2} \quad k_{11}=k_{5}
$$

This demonstrates a regeneration of $\mathrm{N}^{\mathrm{III}}$ species. The formation rate of $\mathrm{HNO}_{2}$ would then be expressed as:

$$
\mathrm{d}\left[\mathrm{HNO}_{2}\right] / \mathrm{dt}=3 \mathrm{k}_{5}\left[\mathrm{HNO}_{3}\right]\left[\mathrm{HNO}_{2}\right]
$$


The surface not being yet saturated, the current would be directly related to the flux of $\mathrm{HNO}_{2}$ and increase exponentially. In our experimental conditions, limitations by both Eqs. 7 or 9 cannot be clearly separated. A fit in logarithmic coordinates gives a first order of magnitude of $k_{5}$ but its value is underestimated. Therefore, we relied on simulations to obtain $k_{5}$ and $k_{7}$. The thermodynamic constants were taken from the literature [6]. A reasonably good fit of the chronoamperogram can be obtained with an initial concentration of $10^{-3}$ mol. $\mathrm{L}^{-1}$ for $\mathrm{HNO}_{2}$ for $k_{5}=1.52 \mathrm{~L} \cdot \mathrm{mol}^{-1} \cdot \mathrm{s}^{-1}$ and $k_{7}=1.00 \times 10^{7} \mathrm{~L} \cdot \mathrm{mol}^{-1} \cdot \mathrm{s}^{-1}$. The product $k_{d e s} \Gamma_{\text {Max }}$ was $1.51 \times 10^{-5}$ mol.cm ${ }^{-2} \cdot \mathrm{s}^{-1}$ to fit the plateau. Taking $\Gamma_{\text {Max }}=4 \times 10^{-10}$ mol.cm ${ }^{-2}$ as suggested by Koper [6] gives $k_{\text {des }}=37.7 \times 10^{3} \mathrm{~s}^{-1}$. All the kinetic constants obtained from the fit are reported in Table 1. Two slight discrepancies are observed. At initial times the experimental decrease is much longer, probably because some initial adsorbates such as $\mathrm{NO}_{2}$ need to be removed first. On the other hand, near the plateau region a slight bump is observed and cannot be explained by our analysis. It involves likely some passivation phenomena of the electrode. This is compatible with our observation of small changes in the plateau current even during the same experiment. It is noticeable that the simulated chronoamperogram is affected if initial amounts of NO or $\mathrm{NO}_{2}$ are introduced. The deduced rate constants are nevertheless only very poorly affected.

Fig. $2 \mathrm{~b}$ shows the concentration gradient of the main electroactive species involved in the reduction of nitric acid after 2 seconds of electrolysis. As expected, when steady state is reached, a large amount of nitric acid is consumed simultaneously with the generation of $\mathrm{HNO}_{2}$. NO is present only in a thin layer near the electrode and as expected cannot coexist with $\mathrm{NO}_{2}$ due to the occurrence of reaction 7. Autocatalysis being limited by NO production at the electrode in this time range, large amounts of $\mathrm{NO}_{2}$ are released in solution, which is compatible to experimental observation of $\mathrm{NO}_{2}$ liberation in the atmosphere.

\section{Conclusions}


The complex nitrate reduction mechanism on a platinum electrode in highly concentrated nitric acid was simplified in order to take into account solely the chemical steps that play a kinetic role. The huge current enhancement due to autocatalysis stems from regeneration of $\mathrm{HNO}_{2}$ in solution. Occurrence of a plateau evidences a limitation by $\mathrm{NO}_{\text {ads }}$ desorption from the electrode surface. Further work will consider hindering of autocatalysis at ultramicroelectrodes because of a radial evacuation of $\mathrm{HNO}_{2}$. 


\section{References}

[1] M. Duca, V. Kavvadia, P. Rodriguez, S.C.S. Lai, T. Hoogenboom, M.T.M. Koper, Journal of Electroanalytical Chemistry, 649 (2010) 59-68.

[2] J. Souza-Garcia, V. Climent, J.M. Feliu, Electrochemistry Communications, 11 (2009) 1515-1518.

[3] F. Balbaud, G. Sanchez, P. Fauvet, G. Santarini, G. Picard, Corrosion Science, 42 (2000) 1685-1707.

[4] P. Fauvet, F. Balbaud, R. Robin, Q.T. Tran, A. Mugnier, D. Espinoux, Journal of Nuclear Materials, 375 (2008) 52-64.

[5] G.E. Dima, A.C.A. De Vooys, M.T.M. Koper, Journal of Electroanalytical Chemistry, 554-555 (2003) 15-23.

[6] M.T. De Groot, M.T.M. Koper, Journal of Electroanalytical Chemistry, 562 (2004) 81-94.

[7] K.J. Vetter, Z. Elektrochem., Ber. Bunsenges. Phys. Chem., 63 (1959) 1189-1191.

[8] G. Schmid, J. Delfs, Z. Elektrochem., Ber. Bunsenges. Phys. Chem., 63 (1959) 1192.

[9] G. Schmid, M.A. Lobeck, Z. Elektrochem., Ber. Bunsenges. Phys. Chem., 73 (1969) 189.

[10] V.P. Razygraev, M.V. Lebedeva, S.A. Kabakchi, Doklady Akademii Nauk Sssr, 288 (1986) 1428-1432.

[11] V.P. Razygraev, M.V. Lebedeva, S.A. Kabakchi, E.Y. Ponomareva, R.S. Balovneva, L.P. Lobanova, Journal of Applied Chemistry of the USSR, 61 (1988) 67-73.

[12] V. Vivier, R. Baddour-hadjean, J.P. Pereira-Ramos, N. Baffier, Journal of Materials Chemistry, 8 (1998) 245-249.

[13] F. Balbaud, G. Sanchez, G. Santarini, G. Picard, European Journal of Inorganic Chemistry, (2000) 665-674.

[14] C.P. Andrieux, A. Merz, J.M. Saveant, Journal of the American Chemical Society, 107 (1985) 6097-6103.

[15] L. Eberson, F. Adner, Acc. Chem. Res., 20 (1987) 53-59

[16] A.C.A. De Vooys, G.L. Beltramo, B. Van Riet, J.A.R. Van Veen, M.T.M. Koper, Electrochimica Acta, 49 (2004) 1307-1314. 
Table 1: Kinetic constants and diffusion coefficients used for the fitting of the experimental results presented in Fig. 2 a.

\begin{tabular}{|l|c|c|c|}
\hline Surface Reactions & & & \\
\hline $\mathrm{HNO}_{2 \text { (ads) }}+\mathrm{e}+\mathrm{H}^{+} \rightleftarrows \mathrm{NO}_{\text {ads }}+\mathrm{H}_{2} \mathrm{O}$ & $\alpha=0.5$ & $\mathrm{k}_{\mathrm{s}}=1 \times 10^{5} \mathrm{~s}^{-1}$ & \\
\hline $\mathrm{Homogeneous} \mathrm{Reactions}$ & $\begin{array}{c}\mathrm{k}_{\mathrm{f}}=2 \times 10^{6} \\
\mathrm{Lmol}^{-1} \mathrm{~s}^{-1}\end{array}$ & $\mathrm{k}_{\mathrm{b}}=2 \times 10^{6} \mathrm{~s}^{-1}$ & $\begin{array}{c}\Gamma_{\max }=4 \times 10^{-10} \\
\mathrm{molcm}^{-2}\end{array}$ \\
\hline $\mathrm{HNO}_{2} \rightleftarrows \mathrm{HNO}_{2 \text { (ads) }}$ & $\begin{array}{c}\mathrm{k}_{\mathrm{f}}=37700 \\
\mathrm{Lmol}^{-1} \mathrm{~s}^{-1}\end{array}$ & $\mathrm{k}_{\mathrm{f}}=37700 \mathrm{~s}^{-1}$ & $\begin{array}{c}\Gamma_{\max }=4 \times 10^{-10} \\
\mathrm{molcm}^{-2}\end{array}$ \\
\hline $\mathrm{NNO}_{2}+\mathrm{NO}_{3}{ }^{-}+\mathrm{H}^{+} \rightleftarrows 2 \mathrm{NO}_{2}+\mathrm{H}_{2} \mathrm{O}$ & $\mathrm{K}=0.013$ & $\mathrm{k}_{\mathrm{f}}=1.52 \mathrm{Lmol}^{-1} \mathrm{~s}^{-1}$ & $\mathrm{k}_{\mathrm{b}}=116.92 \mathrm{Lmol}^{-1} \mathrm{~s}^{-}$ \\
\hline $\mathrm{NO}_{2}+\mathrm{NO}+\mathrm{H}_{2} \mathrm{O} \rightleftarrows 2 \mathrm{HNO}_{2}$ & $\mathrm{~K}=1 \times 10^{8}$ & $\mathrm{k}_{\mathrm{f}}=1 \times 10^{7} \mathrm{Lmol}^{-1} \mathrm{~s}^{-1}$ & $\mathrm{k}_{\mathrm{b}}=0.1 \mathrm{Lmol}^{-1} \mathrm{~s}^{-1}$ \\
\hline $\mathrm{Species}^{-1}$ & $\begin{array}{c}\text { Initial } \\
\text { concentrations } \\
(\mathrm{molL}\end{array}$ & $\mathrm{D}\left(\mathrm{cm}^{-1} \mathrm{~s}^{-1}\right)$ & \\
\hline $\mathrm{HNO}_{2}$ & 0.001 & $1 \times 10^{-5}$ & \\
\hline $\mathrm{NO}^{-5}$ & 0 & $1 \times 10^{-5}$ & \\
\hline $\mathrm{NO}_{3}{ }^{-5}$ & 8 & $1 \times 10^{-5}$ & \\
\hline $\mathrm{NO}_{2}$ & 0 & $1 \times 10^{-5}$ & \\
\hline
\end{tabular}


Figure 1: Linear potential scan of a $250 \mu \mathrm{m}$ in radius Pt electrode in a $8 \mathrm{M} \mathrm{HNO}_{3}$ solution at $10 \mathrm{mVs}^{-1}($ a), and evolution of the current measured on the plateau at $0 \mathrm{~V} / \mathrm{SSE}$ as a function of the scan rate (b)
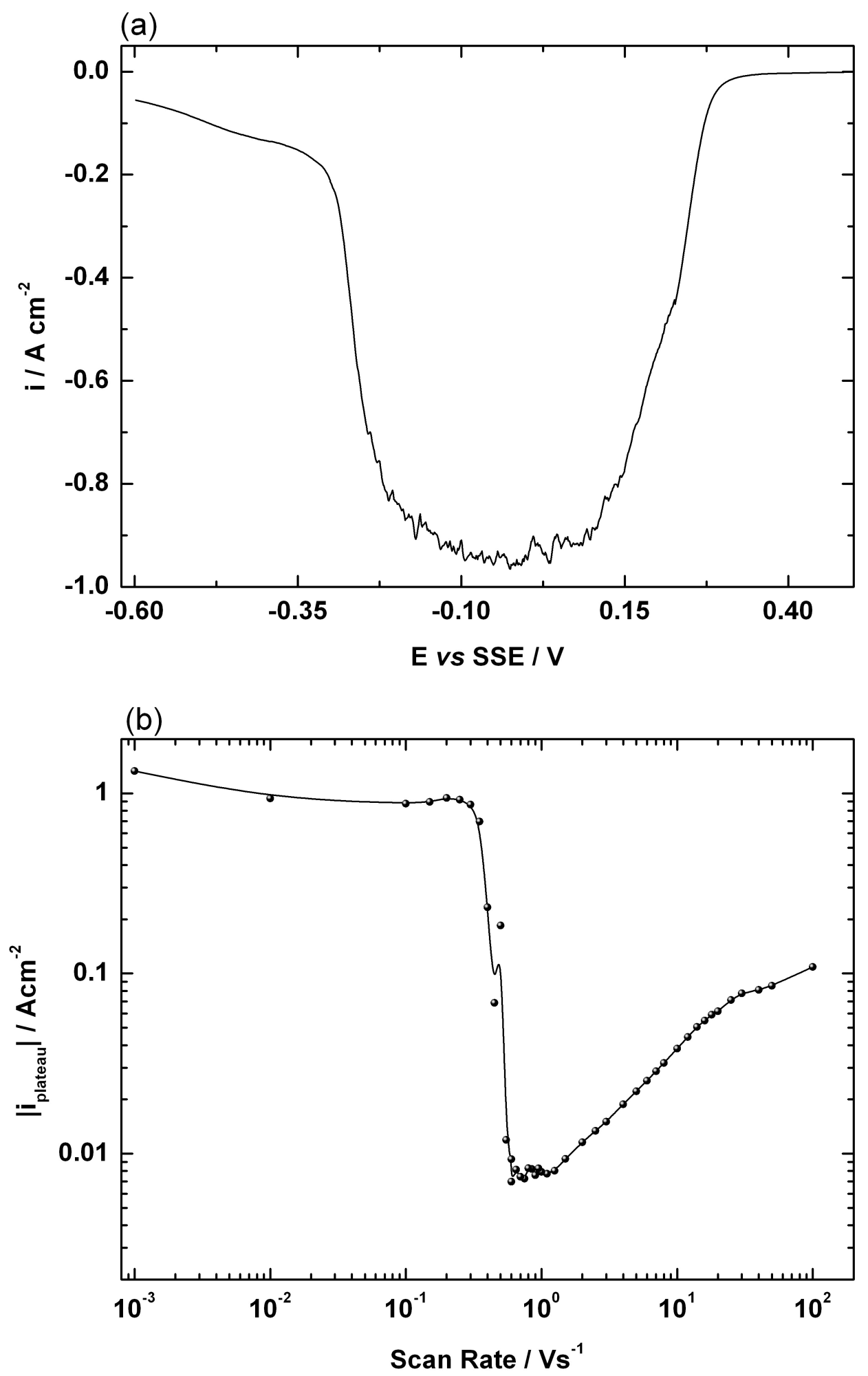
Figure 2: Chronoamperometric response to a potential step from the open circuit potential to $0 \mathrm{~V} / \mathrm{SSE}$ of a $250 \mu \mathrm{m}$ in radius Pt electrode in a $8 \mathrm{M} \mathrm{HNO}_{3}$ solution (a), the inset is a zoom on the short time domain, and variations of the concentration species (b), the inset is a zoom of the domain close to the interface.
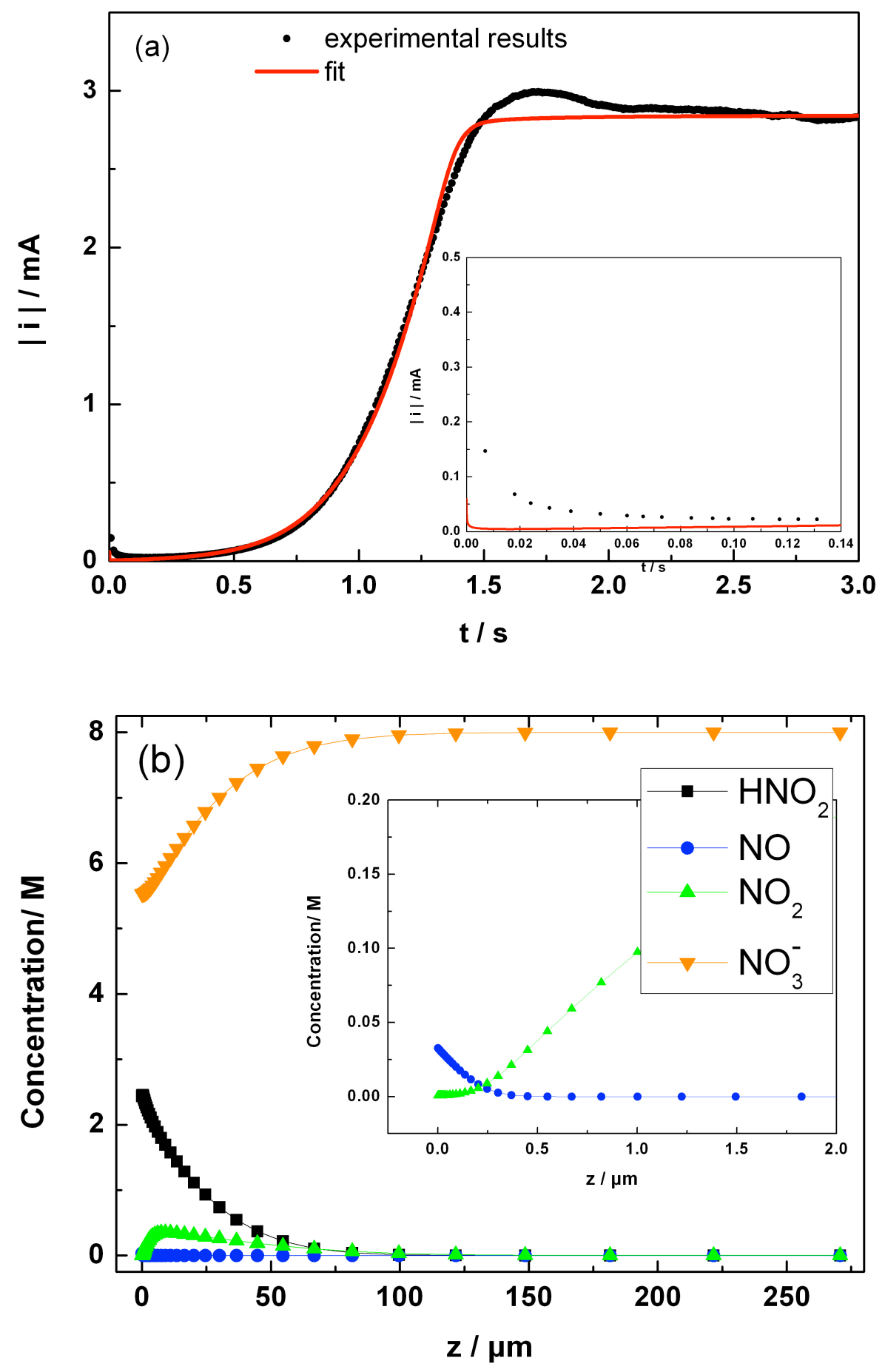